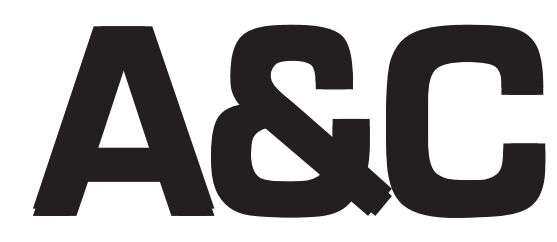

Revista de Direito Administrativo \& Constitucional

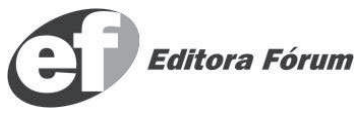

ISSN 1516-3210 


\section{A\&C REVISTA DE DIREITO ADMINISTRATIVO \& CONSTITUCIONAL}

\section{IPDA}

Instituto Paranaense

de Direito Administrativo

Direção Geral

Romeu Felipe Bacellar Filho

Direção Editorial

Paulo Roberto Ferreira Motta

Direção Executiva

Emerson Gabardo

Conselho de Redação

Edgar Chiuratto Guimarães

Adriana da Costa Ricardo Schier

Célio Heitor Guimarães

\section{Conselho Editorial}

Adilson Abreu Dallari (Brasil) Alice Gonzales Borges (Brasil) Antonello Tarzia (Itália)

Carlos Ari Sundfeld (Brasil)

Carlos Ayres Britto (Brasil)

Carlos Delpiazzo (Uruguai)

Cármen Lúcia Antunes Rocha (Brasil)

Celso Antônio Bandeira de Mello

(Brasil)

Clèmerson Merlin Clève (Brasil)

Clovis Beznos (Brasil)

Enrique Silva Cimma (Chile)

Eros Roberto Grau (Brasil)

Fabrício Motta (Brasil)

Guilhermo Andrés Muñoz - in memoriam

(Argentina)

Jaime Rodríguez-Arana Muñoz (Espanha)

Jorge Luís Salomoni - in memoriam
(Argentina)
José Carlos Abraão (Brasil)
José Eduardo Martins Cardoso (Brasil)
José Luís Said (Argentina)
José Mario Serrate Paz (Uruguai)
Juan Pablo Cajarville Peruffo (Uruguai)
Juarez Freitas (Brasil)
Julio Rodolfo Comadira - in memoriam
(Argentina)
Luís Enrique Chase Plate (Paraguai)
Lúcia Valle Figueiredo (Brasil)
Manoel de Oliveira Franco Sobrinho -
in memoriam (Brasil)
Marçal Justen Filho (Brasil)
Marcelo Figueiredo (Brasil)

\author{
Maria Cristina Cesar de Oliveira (Brasil) \\ Nelson Figueiredo (Brasil) \\ Odilon Borges Junior (Brasil) \\ Pascual Caiella (Argentina) \\ Paulo Eduardo Garrido Modesto (Brasil) \\ Paulo Henrique Blasi (Brasil) \\ Paulo Neves de Carvalho - in memoriam \\ (Brasil) \\ Paulo Ricardo Schier (Brasil) \\ Pedro Paulo de Almeida Dutra (Brasil) \\ Regina Maria Macedo Nery Ferrari (Brasil) \\ Rogério Gesta Leal (Brasil) \\ Rolando Pantoja Bauzá (Chile) \\ Sérgio Ferraz (Brasil) \\ Valmir Pontes Filho (Brasil) \\ Weida Zancaner (Brasil) \\ Yara Stropa (Brasil)
}

A246 A\&C Revista de Direito Administrativo \& Constitucional. ano 3, n. 11, jan./mar. 2003. Belo Horizonte: Fórum, 2003.

Trimestral

ano 1, n. 1, 1999 até ano 2, n. 10, 2002 publicada pela Editora Juruá em Curitiba

ISSN 1516-3210

1. Direito Administrativo. 2. Direito Constitucional. I. Fórum.

CDD: 342

CDU: 33.342

(C) 2008 Editora Fórum Ltda.

Todos os direitos reservados. É proibida a reprodução total ou parcial, de qualquer forma ou por qualquer meio eletrônico ou mecânico, inclusive através de processos xerográficos, de fotocópias ou de gravação, sem permissão por escrito do possuidor dos direitos de cópias (Lei nº 9.610, de 19.02.1998).

Editora Fórum Ltda

Editor responsável: Luís Cláudio Rodrigues Ferreira

Av. Afonso Pena, 2770 - 15\%16ªndar - Funcionários

CEP 30130-007 - Belo Horizonte/MG - Brasil

Coordenação editorial: Olga M. A. Sousa

Tel.: 08007043737

Internet: www.editoraforum.com.br

Pesquisa jurídica: Fátima Ribeiro - OAB/MG 74868

Revisora: Lourdes Nascimento

Projeto gráfico e diagramação: Luis Alberto Pimenta

e-mail: editoraforum@editoraforum.com.br

Bibliotecária: Fernanda de Paula Moreira - CRB 2900 - 6a região

Esta publicação está indexada no Ulrich's Periodicals Directory

Os conceitos e opiniões expressas nos trabalhos assinados são de responsabilidade exclusiva de seus autores.

Impressa no Brasil / Printed in Brazil

Distribuída em todo o Território Nacional 


\title{
A pesagem dos veículos ônibus do transporte coletivo rodoviário interestadual de passageiros nas estradas federais
}

\author{
Sérgio Roberto Maluf \\ Especialista em Direito Administrativo pelo Instituto de Direito Romeu Felipe Bacellar.
}

\begin{abstract}
Resumo: O presente artigo aborda a questão da pesagem dos veículos ônibus do transporte coletivo rodoviário interestadual e de passageiros nas estradas federais. Inicialmente trata-se do Estado de Direito, o qual detém poderes e limitações decorrentes da lei. Em seguida, analisam-se alguns aspectos sobre as rodovias federais e a estrutura legal aplicável. Trata-se da normatividade do trânsito, especialmente questões sobre capacidade e licença dos veículos sujeitos à pesagem. No que se refere aos veículos ônibus, vários dispositivos do Código de Trânsito Brasileiro são analisados. Demonstramse alguns óbices no tocante à pesagem do veículo ônibus, e do seu uso derivado para encomendas ou cargas. Trata-se das infrações e notificações previstas no Código de Trânsito Brasileiro. Sustenta-se que a lotação de um veículo de transporte de passageiros deve ser aferida em número de pessoas. Por fim, elencam-se alguns pontos que cabe aos proprietários de veículos requerer, quando operam transporte coletivo rodoviário.
\end{abstract}

Palavras-Chave: Veículo ônibus. Transporte coletivo rodoviário. Rodovias federais. Estado de Direito. Pesagem. Código de Trânsito Brasileiro. Passageiros. Encomendas e cargas.

Sumário: 1 Do Estado de Direito - 2 Da estrutura estatal federal - 3 Do ordenamento de trânsito - 4 Do requisito "peso" para transitar - 5 Do veículo ônibus - 6 Do agir estatal federal - 7 Do uso derivado do veículo ônibus - 8 Das infrações e suas notificações - 9 Conclusões

\section{Do Estado de Direito}

Uma sociedade que pretenda perseguir melhor convívio, com busca organizada de objetivos que individualmente ter-se-ia como de impossível concretização, institui um "Estado" para que se ocupe de determinadas funções quando não da execução de atividades fundamentais àqueles que o constituíram.

O Estado, uma vez constituído, não assume a totalidade do poder, não raro estampar-se, nas suas constituições (tal como na Carta brasileira), que todo poder emana do povo e em nome dele será exercido.

É anotação que em duas variantes caminha: a um, demonstra que o Estado é mero executor da vontade popular, traduzida, em nosso seio,

A\&C R. de Dir. Administrativo \& Constitucional, Belo Horizonte, ano 8, n. 33, p. 115-134, jul./set. 2008 
pela legislação posta; a dois, faculta ao ente estatal o poder de exigir as normas (ditadas pelo povo), legitimando seu agir. O povo institui normas, expressão de sua vontade, que ao Estado cabe executar e exigir.

O Estado detém, desde a instituição do estado moderno de direito, poderes e também limitações. Ao tempo em que conferido lhe é poder, através da legislação existente à época em um território, também lhe são ditadas limitações. Assim, a norma assume papel dúplice: confere poderes em diploma que também pode limitá-los. É o cerne de um Estado de Direito.

Princípio basilar que, nas irretocáveis palavras de Celso Antônio Bandeira de Mello, ${ }^{1}$ se nos apresenta como sendo de legalidade:

Para avaliar corretamente o princípio da legalidade e captar-lhe o sentido profundo cumpre atentar para o fato de que ele é a tradução jurídica de um propósito político: o de submeter os exercentes do poder em concreto o administrativo - a um quadro normativo que embargue favoritismos, perseguições ou desmandos.

Tem-se, então, que há submissão, completa, dos administradores, à lei. No que possível traçar diferença entre os particulares e os detentores do poder: enquanto àqueles primeiros é dado fazer tudo que a lei não veda, àqueles outros somente é dado fazer o que determinado em lei. Impossível, pois, ao governante ou quem lhe faça as vezes, ter conduta diversa da lei ou mesmo conduta que não encontre óbice legal. Silente a norma, não pode o Estado agir. A ele, enquanto construção da sociedade, só é dado cumprir e exigir o que normatizado esteja.

O Estado brasileiro é tido, então, como Estado regido por normas emanadas do povo. É, destarte, um Estado de Direito. O ente estatal, consoante os ensinamentos já postos, não pode atuar com o fito de perseguir, individualizar, exacerbar-se em suas funções. Por tal, já o art. $5^{\circ}$, II, da Carta da República de 1988 vem trazer garantias ao cidadão: "ninguém será obrigado a fazer ou deixar de fazer alguma coisa senão em virtude de lei”. Protegido o cidadão, impõe-se limitação ao agir do Estado, cingindoo, entre outros, à observância da legalidade: "Art. 37 A administração pública direta e indireta dos Poderes da União, dos Estados, do Distrito Federal, e dos Municípios obedecerá aos princípios da legalidade, impessoalidade, moralidade, publicidade e eficiência...”.

BANDEIRA DE MELLO, Celso Antônio. Curso de direito administrativo. 13. ed. rev., atual. e ampl. São Paulo: Malheiros, 2001. p. 71.

A\&C R. de Dir. Administrativo \& Constitucional, Belo Horizonte, ano 8, n. 33, p. 115-134, jul./set. 2008 
Resultante que dará contornos ao ato administrativo, que por todos ensina Celso Antônio Bandeira de Mello: ${ }^{2}$

Portanto, a função do ato administrativo só poderá ser a de agregar à lei nível de concreção; nunca lhe assistirá instaurar originariamente qualquer cerceio a direitos de terceiros. (grifamos)

Inquestionável o Estado brasileiro enquanto Estado (Democrático) de Direito. Por tal, subordina-se o Estado à vontade popular e aos ditames da legislação. Impossível ao agente adotar proceder diverso da norma ou pretender inaugurar regramento que não seja aquele previamente definido na norma. Esteira em que, com pena de ouro, ensina Diogo de Figueiredo Moreira Neto: ${ }^{3}$

O Estado de Direito, o que se subordina à lei, não é só aquele em que a legislação está condicionada por uma Constituição e em que a jurisdição garante sua aplicação na solução dos conflitos de interesses, mas aquele em que a administração pública está totalmente submetida ao princípio da legalidade.

A norma, pois, apresenta-se como instrumento balizador do agir estatal, devendo o Estado estrita obediência a ela, já que "não existe qualquer liberdade no agir do Estado, atuando a lei como seu único e próprio fundamento de ação". ${ }^{4}$

Cimentado o conceito de Estado de Direito, demonstrada a opção constitucional de aplicação do princípio norteador da legalidade no agir público, passemos a citar, em espécie, a atividade estatal que busca aplicar legislação específica para trânsito, quando considerado o tráfego de veículos em estradas brasileiras. Preliminarmente, em se tratando de estradas federais, necessária breve visualização da estrutura estatal aplicável.

\section{Da estrutura estatal federal}

No tocante aos transportes, conceito amplo, onde inseridas estão as rodovias federais, impende ser considerada, em primeiro plano legislativo, a Constituição Federal. O Texto Maior atribui à União competência (comum aos Estados, Distrito Federal e Municípios) para zelar pelo patrimônio público.

MOREIRA NETO, Diogo de Figueiredo. Curso de direito administrativo: parte introdutória, parte geral e parte especial. Rio de Janeiro: Forense, 2005. p. 46.

4 Ibidem, p. 81.
}

A\&C R. de Dir. Administrativo \& Constitucional, Belo Horizonte, ano 8, n. 33, p. 115-134, jul./set. 2008 
Uma rodovia, construída com recursos públicos, provenientes das prestações tributárias instituídas, passa a integrar, por óbvio, o patrimônio público. Decorrente da aplicação de recursos provenientes do erário federal, imobilizando-se onde construída, integra o patrimônio da União, tornando-se pública e, pelo que investido em construção, desapropriações, etc., passa a ter valor patrimonial passível de aferição. É, portanto, um patrimônio, que idealizado e concretizado pelo Estado, público.

A Constituição determina competência privativa à União, para legislar sobre trânsito e transporte (art. 22, XI, CR/88). Afeto à matéria, o transporte, de bens e pessoas, insere-se naquela competência, ao que, aprovada pelo Congresso Nacional, instituiu-se, através da Lei ${ }^{\circ}$ 10.233/2001, o Sistema Nacional de Viação (SNV). Tal sistema é composto pela infraestrutura viária (no caso em tela, as estradas) sob jurisdição da União, dos Estados, do Distrito Federal e dos Municípios (art. $2^{\circ}$ ).

Contido no Sistema Nacional de Viação está o Sistema Federal de Viação, abrangendo a malha arterial básica do SNV, estando sob jurisdição da União (elementos físicos da infra-estrutura viária existente - art. $3^{\circ}$ e parágrafo único, Lei $\left.n^{\circ} 10.233 / 2001\right)$. Destaque-se, por fim, que é objetivo essencial do Sistema Federal de Viação, entre outros, "garantir a operação racional e segura dos transportes de pessoas e bens" (art. $4^{\circ}$, II, Lei $\left.{ }^{\circ} 10.233 / 2001\right)$.

Com o fito de desenvolver, in concreto, as diretrizes do Sistema Federal de Viação, veio aquele mesmo diploma (Lei no 10.233/2001) criar e instituir o Departamento Nacional de Infra-Estrutura de Transportes (DNIT). À Autarquia, pessoa jurídica de direito público, vinculada ao Ministério dos Transportes, conferiu a Lei competência para "fiscalizar, autuar, aplicar as penalidades e medidas administrativas cabíveis, relativas a infrações por excesso de peso, dimensões e lotação dos veículos, bem como notificar e arrecadar as multas que aplicar", diretamente ou mediante convênio, igualando-a a órgão executivo rodoviário, com competência jurisdicional determinada para a União.

Dentre as funções exercidas então pelo DNIT, deve a Autarquia, com objetivo de manter o pavimento das rodovias federais, proceder, diretamente ou mediante convênio, à verificação do peso dos veículos, pautandose, repise-se, pelo que estritamente disposto na legislação. Plexo normativo que, doravante, é objeto de análise.

A\&C R. de Dir. Administrativo \& Constitucional, Belo Horizonte, ano 8, n. 33, p. 115-134, jul./set. 2008 


\section{Do ordenamento de trânsito}

A Constituição da República de 1988 determina ser competência exclusiva da União legislar sobre trânsito (art. 22, XI). Para o tema, tem-se, então, que somente a União pode editar normas que, pelo que fartamente ensinado, ao tempo em que também obrigam a Administração Pública, legitimam-na a exigir sua obediência dos particulares.

No tocante ao tema trânsito, além da Constituição que deve ser observada quando da análise de qualquer diploma inferior (principalmente quanto ao precitado princípio da legalidade), desponta com vigor o Código de Trânsito Brasileiro (Lei no 9.503/97). O Código, Lei nacional, obriga a todos (União, Estados, Municípios e Distrito Federal), exigindo conduta dos cidadãos e delineando o agir público.

$\mathrm{O}$ CTB, como forma de dar concretude às suas disposições, institui o Sistema Nacional de Trânsito, composto de órgãos necessários às atividades de planejamento, administração, normatização, pesquisa, registro e licenciamento dos veículos, fiscalização e julgamento de infrações e recursos, entre outras funções listadas no art. $5^{\circ}$ do CTB.

A Lei, vazada e rotulada por Código de Trânsito Brasileiro, não pode prever todas as situações do mundo fático. Necessário, então, órgão normativo que seja competente para disciplinar as questões do Código, bem como exarar aclaramentos e tratativas para as inúmeras situações não previstas, em tese, pela Lei. Nesta esteira de normatividade posterior, desponta o Conselho Nacional de Trânsito - CONTRAN (art. 7º I), apto a, entre outras, estabelecer normas regulamentares exigidas pelo próprio CTB (art. 12, I).

Destarte, para determinadas situações ou regramentos, o próprio Código de Trânsito Brasileiro dita norma aberta, conferindo competência para o Conselho Nacional de Trânsito regulá-la, exarando a necessária Resolução.

É o que se poderá verificar, cerceado o foco da abordagem proposta, à pesagem dos veículos.

\section{Do requisito "peso" para transitar}

O Código de Trânsito Brasileiro determina, em seu art. 99, que somente pode transitar pelas vias terrestres veículo cujo peso e dimensões não ultrapassarem os limites estabelecidos pelo CONTRAN:

A\&C R. de Dir. Administrativo \& Constitucional, Belo Horizonte, ano 8, n. 33, p. 115-134, jul./set. 2008 
Art. 99. Somente poderá transitar pelas vias terrestres o veículo cujo peso e dimensões atenderem aos limites estabelecidos pelo CONTRAN.

$\S 1^{\circ} \mathrm{O}$ excesso de peso será aferido por equipamento de pesagem ou pela verificação de documento fiscal, na forma estabelecida pelo CONTRAN.

$\S 2^{\circ}$ Será tolerado um percentual sobre os limites de peso bruto total e peso bruto transmitido por eixo de veículos à superfície das vias, quando aferido por equipamento, na forma estabelecida pelo CONTRAN.

$\S 3^{\circ}$ Os equipamentos fixos ou móveis utilizados na pesagem de veículos serão aferidos de acordo com a metodologia e na periodicidade estabelecidas pelo CONTRAN, ouvido o órgão ou entidade de metrologia legal.

Visualiza-se, já, uma norma aberta, ${ }^{5}$ que requer complementação (no caso em tela, os limites de definição posterior pelo CONTRAN). É momento em que devemos cindir nosso pensamento para determinar momentos de boa aplicação da Lei.

O art. 21 do Código confere competência para os órgãos executivos rodoviários, no caso ora abordado, o Departamento nacional de InfraEstrutura de Transportes (DNIT), para fiscalizar, autuar, aplicar penalidades e medidas administrativas relativas às infrações de excesso de peso e dimensões nas rodovias, no âmbito de sua circunscrição (art. 21, VIII). Antes de estar em uma rodovia, deve o veículo, porém, obter o necessário licenciamento para trânsito. $\mathrm{O}$ art. 22 do CTB diz ser competência dos órgãos ou entidades executivos de trânsito dos Estados e do Distrito Federal vistoriar, inspecionar, registrar, emplacar e licenciar veículos, respeitadas as normas do Código de Trânsito Brasileiro (art. 22, III).

Impende, ainda, avançarmos até o art. 327, também do Código de Trânsito Brasileiro, para termos que, a partir da publicação daquele diploma (1997), nenhum veículo poderia ser fabricado ou licenciado em desacordo com o que disposto para seus limites de peso e dimensão. É, então, ponto primeiro a ser abordado: antes de transitar por uma via pública, o veículo deve obter a necessária licença para tal.

Licença, em apertada síntese, registre-se, é ato administrativo vinculado, ou seja, ato em que o agente público, preenchidos os requisitos legais, não pode se opor à sua expedição.

Um veículo que regularmente licenciado esteja tem seu peso e dimensões adequadas e enquadradas à legislação vigente, fato a ser comprovado $e$

\footnotetext{
5 Tida por Tércio Sampaio Ferraz Júnior (in Introdução ao estudo do direito: técnica, decisão, dominação. 2. ed. São Paulo: Atlas, 1994. p. 126) como norma dependente: "Dependente é qualquer norma que, não esgotando a disciplina, exige outra".
}

A\&C R. de Dir. Administrativo \& Constitucional, Belo Horizonte, ano 8, n. 33, p. 115-134, jul./set. 2008 
autenticado por qualquer órgão executivo de trânsito estadual ou do Distrito Federal. Comprovada a regularidade, faz constar a Autoridade de Trânsito, no documento dos veículos e em seus cadastros, para os veículos de transporte de passageiros, a capacidade (ao que melhor se denominaria lotação), em número de pessoas, que ele é capaz de transportar.

Mas o art. 99 do CTB, já listado, aborda quesitos necessários para o veículo transitar. Vimos que, para transitar, o veículo deve possuir, anteriormente, a necessária licença, o que comprovaria seu enquadramento nos ditames legais. Momento em que desponta primeiro questionamento: tendo sido um veículo já licenciado, com peso e dimensões coadunados à norma, por que motivo ele não poderia transitar?

Possível é, porém, a um veículo exceder o seu peso, transportando mais do que definido como seu limite, e mesmo exceder suas dimensões, quer seja por implementações após a vistoria para expedição da licença, quer seja por transporte de objetos que avancem por sobre aquelas medidas legalmente aceitas.

Ao tempo em que silencia sobre a forma de aferição do excesso de medidas, o Código de Trânsito Brasileiro determina, naquele mesmo art. 99, que a aferição do peso dar-se-á por medição em equipamento de pesagem ou pelo documento fiscal que discrimine seu valor, considerado percentual de tolerância.

A Resolução no 210/2006 do CONTRAN, respondendo a chamamento do art. 99 do CTB, veio determinar os pesos e dimensões permitidas aos veículos que pretendam obter licenças para trânsito nas vias terrestres nacionais. Às medidas listadas na Resolução do CONTRAN somam-se, quando do trânsito de um veículo, a disposição da Lei $n^{\circ} 7.408 / 85$, que confere percentuais de tolerância, bem como a Resolução $n^{\circ}$ 104/99, com art. $1^{\circ}$ definidor da medição de tara — ou tara mais lotação se for o caso através do PBT (Peso Bruto Total — somatória dos pesos dos eixos).

Ou seja: inicialmente, para obter licença, um veículo deve ter seu peso e dimensões condizentes com o que estabelecido pela Resolução no 210/ 2006 do CONTRAN. Quando trafegando, ${ }^{6}$ pode o veículo ultrapassar os limites — definidos naquela Resolução — em no máximo 5\%, considerado

\footnotetext{
6 Adotamos aqui a expressão "trafegar" ditada por Hely Lopes Meirelles, onde possível falar-se em lotação. Para o autor, "trânsito é o deslocamento de pessoas ou coisas (veículos ou animais) pelas vias de circulação; tráfego é o deslocamento de pessoa sou coisas pelas vias de circulação em missão de transporte. Assim, um caminhão vazio quando se desloca por uma rodovia está em trânsito; quando se desloca transportando mercadoria está em tráfego" (in Direito municipal brasileiro. 14. ed. São Paulo: Malheiros, 2006. p. 444).
} 
o seu Peso Bruto Total (PBT), interpretação que se faz com base no art. $2^{\circ}$ da Lei $\mathrm{n}^{\circ} 7.408 / 85$ (somente poderá haver autuação, nas balanças...).

Temos pois, em síntese do que exposto, que um veículo, ainda que regularmente licenciado, ato em que a Administração Pública tem o dever de verificar sua tara e lotação (esta última - para os veículos de transporte de passageiros — já definida e anotada no próprio Certificado de Registro e Licenciamento de Veículo - CRLV, e tida por lugares ou passageiros permitidos), poderá infringir a norma, despassando os limites de peso quando considerada a sua lotação, ou mesmo se ultrapassados os limites dimensionais para ele definidos. Voltaremos, em breve, aos conceitos aqui sacados de tara e lotação.

Por fim, ao deitarmos vistas sobre o art. 100 do CTB, dedução extraise de que o art. 99, ao falar que somente poderá transitar pelas vias terrestres o veículo cujo peso e dimensões atenderem aos limites estabelecidos, considerou o veículo em si, sem a sua lotação, ao que retornaremos, adiante.

\section{Do veículo ônibus}

Antes de definir quais veículos estão aptos a transitarem (e trafegarem) ou mesmo obterem licença consoante as regras determinadas, faz-se necessário delinear quais tipos de veículos são existentes no regramento do Código de Trânsito Brasileiro para que, de lá, tenhamos o conceito de um veículo ônibus.

Analisado o art. 96 daquele códex, temos que o veículo ônibus é um veículo automotor (quanto a sua tração), de passageiros (quanto à sua espécie) e de aluguel (quanto à sua categoria e para os operadores dos serviços públicos próprios ou impróprios de transporte coletivo rodoviário de passageiros). Tudo conforme disposição expressa do art. 96, inciso, I, alínea “a”, inciso II, alínea "a”, item 9, e inciso III, alínea "d”.

Ainda que sendo um veículo (de transporte) de passageiros, o veículo tipo ônibus não está, por esta adjetivação, dispensado de enquadramento nas normas ditadas pelo Código de Trânsito Brasileiro. Afinal, o art. 99, no tocante ao peso, alude a veículos genericamente, e o art. 100 cita que nenhum veículo poderá transitar com peso superior. Destarte, o veículo tipo ônibus está, como qualquer outro veículo que pretenda utilizar-se de rodovias nacionais, afeto ao que determinado na legislação para aferição de peso e dimensões veiculares.

$\mathrm{O}$ art. 100 do CTB, ao prescrever que "nenhum veículo ou combinação de veículos poderá transitar com lotação de passageiros, com peso bruto

A\&C R. de Dir. Administrativo \& Constitucional, Belo Horizonte, ano 8, n. 33, p. 115-134, jul./set. 2008 
total ou com peso bruto total combinado por eixo, superior ao fixado pelo fabricante, nem ultrapassar a capacidade máxima de tração da unidade tratora", traz à baila conceitos ainda não abordados. Novel terminologia se nos apresenta com os vocábulos lotação e peso bruto total.

O que a princípio desponta como uma infeliz redação pode ser o caminho a ser trilhado pelo intérprete na busca de boa interpretação jurídica. O que se nos afigura como uma possível confusão ou erro do legislador pode, na realidade, ter sido a melhor redação dada ao diploma.

Explicamos.

$\mathrm{O}$ artigo fala em lotação de passageiros e peso bruto total. Inserido um termo em um diploma, repetidamente podemos, no seu próprio seio, quando estranho ao lugar-comum, encontrar definição que lhe dê guarida. Com o Código de Trânsito Brasileiro não é diferente. Esquadrinhado o seu Anexo I (Dos Conceitos e Definições), deparamo-nos com as definições adotadas para aquela terminologia empregada no art. 100. Ao que começamos pelo Peso Bruto Total:

PESO BRUTO TOTAL - peso máximo que o veículo transmite ao pavimento, constituído da soma da tara mais lotação. (grifamos)

Desponta, de plano, que o legislador definiu a lotação de passageiros como algo distinto do que seja a lotação inserida no conceito de Peso Bruto Total. Para a completa definição das terminologias, segue a diligência.

Tara, ainda conforme o Anexo I do CTB, é o peso próprio do veículo, acrescido dos pesos da carroçaria e equipamento, do combustível, das ferramentas e acessórios, da roda sobressalente, do extintor de incêndio e do fluído de arrefecimento, expresso em quilogramas. Temos, assim, que um veículo tem sua tara definida em quantidade de quilogramas, sem que nenhuma pessoa nele esteja, ao que se exclui, inclusive, o condutor.

Lotação, ainda tendo Código de Trânsito Brasileiro como arrimo, é $a$ carga útil máxima, incluindo condutor e passageiros, que o veículo transporta, expressa em quilogramas para os veículos de carga, ou número de pessoas, para os veículos de passageiros (grifamos).

Fácil visualizar, agora, que um caminhão, quando trafegando em uma rodovia, terá o seu Peso Bruto Total (PBT) definido pela somatória da sua tara (peso do veiculo em si) mais a lotação (quilogramas aferidos com a carga transportada, incluindo-se o condutor e eventuais passageiros acompanhantes). Fácil, também, visualizar que um automóvel, quando

A\&C R. de Dir. Administrativo \& Constitucional, Belo Horizonte, ano 8, n. 33, p. 115-134, jul./set. 2008 
trafegando em uma rodovia, terá seu PBT definido pela aferição da sua tara e QUANTIDADE de passageiros transportada.

Explícita determinação: enquanto ao veículo - de transporte de passageiros (e somente a ele) — se pesa para determinar sua tara, aos passageiros embarcados procede-se contagem, para verificar se a lotação de passageiros (em idêntico andar do art. 100 do CTB) é aquela permitida pelo fabricante. Despassado qualquer destes itens, haverá infração à legislação, afrontandose, em ambos os casos, o Peso Bruto Total permitido.

O veículo ônibus, por cristalina exposição feita, é veículo automotor de transporte de passageiros. Assim, a aferição de seu PBT deve passar, necessariamente, pela verificação de sua tara (peso próprio do veículo, acrescido dos pesos da carroçaria e equipamento, do combustível, das ferramentas e acessórios, da roda sobressalente, do extintor de incêndio e do fluído de arrefecimento, expresso em quilogramas) e, processo apartado, pela contagem do número de passageiros (incluído o condutor), verificando-se, assim, sua lotação (carga útil máxima, incluindo condutor e passageiros, que o veículo transporta, expressa em quilogramas para os veículos de carga, ou número de pessoas, para os veículos de passageiros).

Prudente se nos apresenta assim a redação do art. 100. Ao falar em lotação de passageiros, já quis, por certo, o legislador, afastar qualquer possibilidade de se considerar aquela lotação em equivalência a quilogramas, restando, para esta unidade de medida, a apuração, tão-somente, da lotação dos veículos de carga.

\section{Do agir estatal federal}

Conforme já demonstrado, em rodovias federais, exerce o DNIT competência própria, diretamente ou mediante convênio, pesando os veículos ônibus.

Não há, por definição legal específica, procedimentos definidos ao agir estatal. A Resolução no 210, novel instrumento normativo relacionado ao tema, preocupa-se, apenas, em definir as dimensões dos veículos, seus pesos máximos, etc. Não há, em nenhum momento, explícita normatização do PROCESSO de pesagem.

O “Quadro de Fabricantes de Veículos - Versão 4.1", 7 gerado e disponibilizado pelo próprio Departamento Nacional de Infra-Estrutura de Transportes (DNIT), apresenta, em cimentação do que pensamos, classificações que se voltam, mais, aos caminhões.

${ }_{7}^{7}$ Disponível em: <http://www.dnit.gov.br/menu/rodovias/QFV.pdf> . Acesso em: 31 jul. 2007.

A\&C R. de Dir. Administrativo \& Constitucional, Belo Horizonte, ano 8, n. 33, p. 115-134, jul./set. 2008 
Notório que as balanças destinam-se a aferir a tara e, principalmente, a lotação daqueles veículos de carga. Em sua página 3, o referido "Quadro" do DNIT já cita exemplos classificatórios com anotação de caminhões (3C é caminhão simples com $3^{\circ}$ eixo, 3C3 é caminhão simples com 3 eixos +1 reboque com 3 eixos trafegando sem AET, etc.).

Não se extrai, do precitado "Quadro" enfoque firme e robusto para pesagem dos veículos ônibus. Ponto único existente é a descrição de "silhuetas" daqueles tipos de veículos. Despontam, sim, enfoques ditados ao transporte de cargas e veículos responsáveis por tal (caminhões). Também impossível a visualização naquele "Quadro" de qualquer procedimento de pesagem, notadamente quanto à forma de pesagem e a velocidade em que a mesma deve ocorrer para os mais variados tipos de veículos lá listados.

Tenha-se ainda em mente que foi inserto no ordenamento jurídico brasileiro, em 23 de setembro de 1997, o Código de Trânsito Brasileiro ora vigente. Era, e ainda o é, ordenamento de grande impacto na vida cotidiana e nas relações dos cidadãos com o trânsito (motoristas e pedestres).

Um novel e complexo diploma, bem como já o fez o Código Civil Brasileiro de 2002, não se nos apresenta, à época da sua sanção ou promulgação, sem que as relações existentes ou os temas propostos em suas fundamentações ou disposições tenham tratamento intermediário, passageiro, transitório. Assim, o novel Código Civil Brasileiro se nos apresenta com disposições transitórias (artigos 2.028 a 2.046); o Código de Trânsito Brasileiro também tem suas disposições transitórias (artigos 313 a 341), e, por último, mas não menor, a Constituição Federal inaugurou a mesma trilha (ADCT - Ato das Disposições Constitucionais Transitórias).

O legislador dos diplomas, e especificamente o legislador do Código de Trânsito Brasileiro, manifesta sapiência ao determinar como as relações existentes sob a égide de uma lei serão "transitadas" para o novo regramento. Ausente tal prudência, instaurada estaria completa insegurança jurídica, afetando a efetividade de toda e qualquer norma vigente ou lançada ao ordenamento.

Ao legislador do Código de Trânsito Brasileiro não se apresentou aridez de sabedoria. Impôs, ao artigo 231, notadamente em seu inciso V, penalidade para o trânsito de veículos com peso despassado dos limites lá fixados. Assim:

Art. 231. Transitar com o veículo:

$(\ldots)$

A\&C R. de Dir. Administrativo \& Constitucional, Belo Horizonte, ano 8, n. 33, p. 115-134, jul./set. 2008 
$\mathrm{V}$ - com excesso de peso, admitido percentual de tolerância quando aferido por equipamento, na forma a ser estabelecida pelo CONTRAN:

Infração - média;

Penalidade - multa acrescida a cada duzentos quilogramas ou fração de excesso de peso apurado, constante na seguinte tabela:

a) até seiscentos quilogramas - 5 (cinco) UFIR;

b) de seiscentos e um a oitocentos quilogramas - 10 (dez) UFIR;

c) de oitocentos e um a um mil quilogramas - 20 (vinte) UFIR;

d) de um mil e um a três mil quilogramas - 30 (trinta) UFIR;

e) de três mil e um a cinco mil quilogramas - 40 (quarenta) UFIR;

f) acima de cinco mil e um quilogramas - 50 (cinqüenta) UFIR;

Medida administrativa - retenção do veículo e transbordo da carga excedente; (...) (grifamos)

O ditame "na forma a ser estabelecida pelo CONTRAN" remete, sem que arrepsia qualquer desponte, à regulamentação necessária da norma. O legislador prevê que o trânsito, em vias públicas, somente é dado a veículos dentro de determinado limite de peso e que o CONTRAN irá determinar a forma de realização de sua verificação (tipos de equipamentos utilizados na aferição, moldes físicos dos parques de pesagem, velocidade da pesagem, formas de confronta da aferição - repesagem, etc). Inaugura-se, aí, rol de incertezas jurídicas, que resolvente alguma desponta a aclarar.

Carecendo a norma do artigo 231, V, de regulamentação, notadamente aquela que demonstre como a pesagem deverá se proceder, urge ao bom intérprete afastá-la ou, melhor, buscar norma que permita ação até que a necessária regulamentação desponte. Caminho tênue há de ser percorrido, então, até o artigo 323 do CTB, verbis:

Art. 323. O CONTRAN, em cento e oitenta dias, fixará a metodologia de aferição de peso de veículos, estabelecendo percentuais de tolerância, sendo durante este período suspensa a vigência das penalidades previstas no inciso $\mathrm{V}$ do art. 231, aplicando-se a penalidade de vinte UFIR por duzentos quilogramas ou fração de excesso.

Parágrafo único. Os limites de tolerância a que se refere este artigo, até a sua fixação pelo CONTRAN, são aqueles estabelecidos pela Lei n ${ }^{\circ} 7.408$, de 25 de novembro de 1985. (grifamos)

Postando-se com sabedoria, quis o legislador aplicar, em período máximo de 180 dias, penalidade de 20 (vinte) UFIR (Unidade de Referência Fiscal) por duzentos quilogramas ou fração de excesso de peso.

A\&C R. de Dir. Administrativo \& Constitucional, Belo Horizonte, ano 8, n. 33, p. 115-134, jul./set. 2008 
Suspendia-se, também, durante os 180 dias necessários à fixação da metodologia de pesagem, a aplicação do artigo 231, V.

O artigo 231, V, se nos apresenta, então, com condição suspensiva dúplice: sua aplicação depende da dissipação do prazo de 180 (cento e oitenta) dias $e$, também, da apresentação de metodologia, pelo CONTRAN (Conselho Nacional de Trânsito), para a correta aferição de peso. A primeira condição já foi, nesta data, atendida, ou seja: transcorreram os 180 dias requisitados pelas disposições transitórias. Há, porém, óbice ainda remanescente: não há metodologia fixada para aferição de peso.

Não gozando de aplicabilidade, já que não atendidas, ainda, as duas condições suspensivas que lhe são impostas, não pode o Agente Público valer-se do artigo 231, V, para fundamentar seu ato. Restaria análise do artigo 323, que, via inversa, prolatado foi com condição resolutiva: requeria 180 dias para sua aplicabilidade, tempo em que deveria o CONTRAN efetuar pronunciamento onde fixasse a metodologia de aferição. Consumido o prazo, resolver-se-ia aquela norma, não mais tendo eficácia sobre as relações de trânsito.

Depara-se hoje, pois, o ordenamento, com hiato normativo: não há mais vigência a ser emprestada ao artigo 323 do Código de Trânsito Brasileiro, e não há atendimento da dúplice condição suspensiva imposta ao artigo 231, V, do mesmo diploma, defeso ser ele arrimo para atos de qualquer autoridade por não ser vigente.

Age, pois, o DNIT ou seus conveniados, em matéria que silente é o ordenamento legal, já que ausente matéria a disciplinar a pesagem dos veículos. Age, destarte, em clara afronta ao princípio da legalidade quando intenta a prática de ato administrativo sem norma que lhe dê amparo ou legitimidade.

Ainda que considerado aquele agir enquadrado em matéria regulada por norma (em sentindo amplo) — o que não se nos afigura como possível —, só age bem o Estado quando determina como obrigatória a pesagem ao veículo do tipo caminhão (ainda que guardadas ressalvas para este tipo de veículo; cite-se, por exemplo, a impossiblidade de aferição de peso em balanças dinâmicas daqueles veículos que transitam transportando carga líquida). O caminhão, um veículo de carga, pode ter aferida sua lotação pelas balanças (quando existente o necessário regramento). Utilizarse-ia, então, neste caso e para aqueles veículos de carga, equipamentos que se prestam a determinar a quantidade de quilogramas.

A\&C R. de Dir. Administrativo \& Constitucional, Belo Horizonte, ano 8, n. 33, p. 115-134, jul./set. 2008 
Considerado o veículo ônibus, e para verificação de sua tara, a simples aferição dos ditames do fabricante seria suficiente para enquadrar o veículo em situação de legalidade.

Resgatando nossos ensinamentos, temos que o veículo ônibus, para obter seu licenciamento, deve adequar-se às regras de peso determinadas para os veículos, momento em que é verificada sua tara. Licenciado, pois, está o veículo em condições de tráfego.

Ao adentrar uma balança, equipamento suficiente para verificar apenas quantidade de quilogramas (peso ou peso-força como preferem os técnicos da física), poderia o agente, considerado o princípio da legalidade e para um veículo do tipo ônibus, aferir — novamente - a tara do veículo, devendo fazê-lo com desembarque de todos os passageiros, que não podem ser pesados e sim contados, e suas respectivas bagagens, não inseridas que estão em uso derivado do veículo.

\section{Do uso derivado do veículo ônibus}

Questão sempre trazida à baila quando aflora o tema "pesagem" é o transporte, pelos veículos ônibus, de encomendas, ou cargas, como preferem alguns.

Correto, para nós, apresenta-se o tema encomenda, já que ao veículo ônibus, por limitações físicas, não é dada a condução de grandes volumes ou mesmo volumes que representam expressão escalar de peso. Atende, sim, o veículo ônibus, quando possível, aos interesses sociais no transporte de jornais, água para análise, órgãos destinados a transplante, malas postais, entre outras.

Mas, amparo legal que sempre buscamos à nossa fundamentação, não vamos nos esquivar do tema.

Ainda que tendo enquadramento legal como veículo de transporte de passageiros, ao veículo ônibus, por força do art. 109 do CTB, é permitido o transporte de carga, desde que observadas as normas estabelecidas na Resolução n 26 do CONTRAN. É norma que determina ser possível o transporte de carga, em veículos de transporte de passageiros, quando a mesma estiver acomodada em compartimento próprio, separado dos passageiros (bagageiro para os veículos ônibus). ${ }^{8}$

\footnotetext{
8 Art. $1^{\circ} \mathrm{O}$ transporte de carga em veículos destinados ao transporte de passageiros, do tipo ônibus, microônibus, ou outras categorias, está autorizado desde que observadas as exigências desta Resolução, bem como os regulamentos dos respectivos poderes concedentes dos serviços.
}

A\&C R. de Dir. Administrativo \& Constitucional, Belo Horizonte, ano 8, n. 33, p. 115-134, jul./set. 2008 
Assim, estando qualquer eventual encomenda embarcada no veículo, à exceção daquelas de cunho social já citadas, poderia ela, já que não afeta ao veículo ou mesmo aos passageiros, ser pesada, para ter aferição do seu quantum em quilogramas.

Momento em que necessário é aclaramento ou conceituação do termo "carga", adotado amiúde pela legislação, em detrimento do termo "encomenda", mais afeiçoado ao veículo ônibus.

O Código de Trânsito Brasileiro ou disposições normativas posteriores não trazem definição do termo. Por analogia, utilizamo-nos de termo existente na aviação civil, representativo que é do mesmo objeto tido nos veículos ônibus. Da aviação, temos, e de forma que entendemos bem definida, a conceituação de carga:

CARGA: é todo bem transportado em aeronave, com exceção das malas postais, provisões de bordo e bagagens acompanhadas ou extraviadas.

Transferido o conceito para o transporte coletivo rodoviário de passageiros, temos que carga (ou encomenda) é todo bem transportado no bagageiro de um veículo ônibus, que não se apresente como mala postal, provisões ou bagagens dos passageiros.

A conceituação por nós cunhada, pode ainda ser acrescida, com uso da Resolução n ${ }^{\circ}$ 16/2002 da Agência Nacional de Transportes Terrestres (ANTT), do conceito de bagagem: conjunto de objetos de uso pessoal do passageiro, devidamente acondicionado transportado no bagageiro do veículo, sob responsabilidade da empresa.

Por fim, para que dúvida não reste do que deva ser tido como item não-ligado ao passageiro, passível, pois, de pesagem, poder-se-ia, em fuga do conceito de carga, adotar o conceito de encomendas. É, porém, a mesma Resolução n 16/2002 da ANTT que irá gravar definição: objetos de propriedade de pessoa física ou jurídica, não incluído como sendo de uso pessoal, transportados no bagageiro do ônibus, devidamente acompanhado de documentação fiscal. Assemelham-se, inconteste, os conceitos de cargas e encomendas.

Art. $2^{\circ} \mathrm{A}$ carga só poderá ser acomodada em compartimento próprio, separado dos passageiros, que no ônibus é o bagageiro.

Art. $3^{\circ}$ Fica proibido o transporte de produtos considerados perigosos conforme legislação específica, bem como daqueles que, por sua forma ou natureza, comprometam a segurança do veículo, de seus ocupantes ou de terceiros.

Art. $4^{\circ}$ Os limites máximos de peso e dimensões da carga serão os fixados pelas legislações existentes na esfera federal, estadual ou municipal.

A\&C R. de Dir. Administrativo \& Constitucional, Belo Horizonte, ano 8, n. 33, p. 115-134, jul./set. 2008 
Resumo faz-se, aqui, necessário.

Em um veículo ônibus, em se buscando determinar o seu peso, considerados devem ser sua tara e todas as encomendas transportadas (aferidas em quilogramas). Ou seja: em um processo de pesagem, se assim bem agir o Poder Público, em obediência ao princípio da legalidade, deve o agente ater-se à pesagem do veículo para apurar sua tara (consoante definição do Código de Trânsito Brasileiro), acrescida da medição em quilogramas dos volumes existentes em seus bagageiros e que possam ser caracterizados como carga ou encomenda. Necessário sejam retirados do processo de pesagem os passageiros, apurados mediante contagem, e também suas bagagens (até 30 quilogramas no bagageiro e até 5 quilogramas no porta-embrulhos), que devem, por disposição regulamentar (Resolução n ${ }^{\circ}$ 1.432/2006, da ANTT) e não vedação do CTB, ser transportada pelos operadores do transporte coletivo rodoviário interestadual de passageiros.

Cite-se, ainda, que é impedido de transportar qualquer espécie de carga ou encomenda o veículo ônibus que esteja realizando fretamento interestadual, de competência da Agência Nacional de Transportes Terrestres (ANTT). A Resolução $\mathrm{n}^{\circ} 1.166 / 2005$, ao regrar o transporte interestadual de passageiros, realizado sob a modalidade de fretamento, veda, em seu art. 46, V, o transporte de bagagem desacompanhada, encomenda ou mercadoria. A este veículo, realizando este modal interestadual de transporte, a única possível aferição em um posto de pesagem, através de balança, seria a comprovação de sua tara.

\section{Das infrações e suas notificações}

Regramento com caracteres de diploma de especialidade em trânsito, o Código de Trânsito Brasileiro, em seu art. 257, determina que as penalidades podem ser impostas ao proprietário (quando inerentes ao veículo em si), ao condutor (quando inerentes à condução), ao embarcador (quando inerentes ao embarque de $\operatorname{carg} a$ ) ou ao transportador (quando decorrentes do transporte da $\operatorname{carga}$ ).

Possível ainda, regra do $\S 1^{\circ}$ daquele art. 257 , a imposição de penalidade concomitantemente a proprietários e condutores quando houver responsabilidade solidária.

Os parágrafos $2^{\circ}$ e $3^{\circ}$ apartam, conforme a situação, a imposição de penalidades para proprietário e condutor. Para os veículos ônibus - que não estejam realizando fretamento - impende por ressalto no que ditado pelos parágrafos $4^{\circ}, 5^{\circ}$ e $6^{\circ}$ :

A\&C R. de Dir. Administrativo \& Constitucional, Belo Horizonte, ano 8, n. 33, p. 115-134, jul./set. 2008 


\section{Art. $257(\ldots)$}

$\S 4^{\circ} \mathrm{O}$ embarcador é responsável pela infração relativa ao transporte de carga com excesso de peso nos eixos ou no peso bruto total, quando simultaneamente for o único remetente da carga e o peso declarado na nota fiscal, fatura ou manifesto for inferior àquele aferido.

$\S 5^{\circ} \mathrm{O}$ transportador é o responsável pela infração relativa ao transporte de carga com excesso de peso nos eixos ou quando a carga proveniente de mais de um embarcador ultrapassar o peso bruto total.

$\S 6^{\circ} \mathrm{O}$ transportador e o embarcador são solidariamente responsáveis pela infração relativa ao excesso de peso bruto total, se o peso declarado na nota fiscal, fatura ou manifesto for superior ao limite legal.

(...)

$\mathrm{O} \S 4^{\circ}$ atribui responsabilidade ao embarcador, nas infrações relativas ao transporte de carga com excesso de peso quando for o único remetente da $\operatorname{carga}$. $\mathrm{O} \S 5^{\circ}$, por sua vez, dita responsabilidade ao transportador pela infração relativa ao transporte de carga, com excesso de peso, quando proveniente de mais de um embarcador. Por fim, transportador e embarcador são solidários $\left(\S 6^{\circ}\right)$ pelo excesso de peso, quando apresentarem nota fiscal ou manifesto (da carga) superior ao limite legal.

Inconteste que as penalidades têm como objetivo o veículo de transporte de carga, e não um veículo de transporte de passageiros. Não é dado, este, a ter embarcador ou transportador em pessoas distintas. Ainda que considerada a utilização derivada do veículo ônibus (item 7), quando efetuando o transporte de encomendas, não se nos apresenta figura de embarcador ou transportador. Se nos apresenta, tão-somente, a figura do proprietário do veículo ônibus, ou, em última análise, um transportador.

Considerado então o veículo ônibus e o errôneo excesso de peso (pelo que demonstrado no procedimento de apuração das infrações aplicadas), incorre em novo pecado o DNIT quando apõe, em seus formulários de notificação de autuação, campos para indicação de condutor. É proceder que leva o administrado a imaginar penalização em dobro por nãoindicação de condutor e, induzido a erro, lá anotar nome de condutor que não deve ter pontos alguns lançados à sua carteira de habilitação, já que infração do proprietário do veículo.

Sobre o tema, assim já se pronunciou o Conselho Estadual de Trânsito de Santa Catarina (Parecer $n^{\circ}$ 004/2004, da lavra do Relator José Vilmar Zimmermann): ${ }^{9}$

\footnotetext{
9 Disponível em: <http://www.cetran.sc.gov.br/pareceres/parecer004.htm>. Acesso em: 31 jul. 2007.
} 
Em suma, sendo a infração objeto do presente estudo de responsabilidade exclusiva do embarcador e do transportador, e sendo que estes geralmente são Pessoas Jurídicas, o cômputo de pontos a cada infração cometida (art. 259 CTB) são inviáveis, posto que as Pessoas Jurídicas, por óbvio, não dirigem veículos.

$(\ldots)$

Por fim, entendo que somente é possível o cômputo da pontuação por infração ao artigo 231, V, CTB, quando for o transportador uma pessoa física que esteja dirigindo o veículo no momento da abordagem e constatação do excesso de peso, isto, ainda, somente quando a carga for proveniente de mais de um embarcador.

Em epílogo, destaque deve ser dado, ainda, à pontuação, indevida já que o proprietário pessoa jurídica. Tem anotado a Administração Pública, maculando o ato administrativo com vício insanável de ilegalidade, o número de 5 (cinco) "Pontos na CNH" nos Autos de Infração (do DNIT), contrariando o que vazado no Código de Trânsito Brasileiro.

Cristalina a anotação, no art. 231, V, que transitar com o veículo com excesso de peso seria infração média. A infração média, consoante ainda o diploma de trânsito, precisamente em seu art. 259, inciso III, aponta para cômputo de 4 (quatro) pontos na Carteira Nacional de Habilitação do condutor.

\section{Conclusões}

Pelo que exposto, visualizam-se - com ressalvas - contornos de legalidade nos processos de pesagem realizados pelo DNIT, quando abordados os veículos do tipo caminhão, ou outros que enquadrados estejam na categoria de transporte de cargas, para aferição de suas taras e lotações, determinadas que devam ser em quilogramas, consoante o Código de Trânsito Brasileiro. Para veículos ônibus, porém, age em patente ilegalidade o agente público quando realiza pesagem dos passageiros, já que a lotação de um veículo de transporte de passageiros deve ser aferida em número de pessoas.

Às empresas operadoras do transporte coletivo rodoviário interestadual de passageiros, porém, não é dado evitar a pesagem ou mesmo realizá-la de forma que visualizem como correta. Evitando-se a pesagem, em entendimento de que a aferição da lotação não é possível em uma balança, e a tara já foi verificada ao momento do licenciamento, infração será cometida, considerado o mal agir público que exara atos administrativos pictóricos (placas de sinalização) onde erroneamente há determinação de obrigatoriedade de pesagem dos veículos ônibus. Haverá,

A\&C R. de Dir. Administrativo \& Constitucional, Belo Horizonte, ano 8, n. 33, p. 115-134, jul./set. 2008 
pois, enquadramento em sanção prevista no Código de Trânsito Brasileiro (art. 209).

Realizar o processo com a retirada dos passageiros seria processo rechaçado pelo agente público operador do equipamento, quando não impossível de ser realizada, fruto da infra-estrutura ofertada pelas praças de pesagem, sujeitando os usuários, entre outras, à intempérie.

Assim, cabe aos proprietários dos veículos ônibus, quando operando transporte coletivo rodoviário interestadual de transporte de passageiros e trafegando por rodovias federais de competência fiscalizatória do DNIT, requerer:

a) a expedição de Certidão declaratória de seus direitos, em prazo de 15 (quinze) dias (Lei n ${ }^{\circ}$ 9.051/2005), de forma a:

i) dispensar do processo de pesagem os seus veículos ônibus naquelas estradas, com balanças de pesagem operadas pela Autarquia ou conveniadas, conferindo, em homenagem a princípio constitucional, tratamento isonômico aos veículos outros de transporte de passageiros (automóveis) que não são pesados, ou

ii) não isentado o processo de pesagem, determinar, em homenagem ao princípio da legalidade, a pesagem dos veículos em estrita observância à legislação vigente, retirando, ao momento da aferição, os passageiros e suas bagagens do interior de cada um deles.

b) em função dos vícios no processo de pesagem, já que efetuada a medição em quilogramas de carga útil onde o Código Brasileiro de Trânsito determina tão-somente contagem (passageiros); dos vícios de legalidade na anotação de pontos (ainda que inaplicáveis ao caso) e disponibilização de formulário para indicação de condutor; do vício de legalidade decorrente da aplicação de artigo ainda não vigente (art. 231) combinado com outro não mais vigente (art. 323), todos a atingir aquele ato maculando de forma insanável, que determine a Administração Pública o cancelamento de todos os Autos de Infração já lavrados, com arquivamento dos processos administrativos deles decorrentes, exercendo o poder de autotutela que lhe é conferido (Súmula no $346 / \mathrm{STF}$ ) e homenageando o princípio da legalidade que deve nortear os atos públicos em geral.

c) a imediata retirada das Notificações de Autos de Infração realizada em veículos ônibus, quando realizadas em escorreita obediência às normas vigentes (não considerando o peso dos passageiros

A\&C R. de Dir. Administrativo \& Constitucional, Belo Horizonte, ano 8, n. 33, p. 115-134, jul./set. 2008 
embarcados), do "Formulário de Indicação do Condutor Infrator - FICI", já que inaplicável ao caso de pesagem daqueles tipos de veículos.

Informação bibliográfica deste texto, conforme a NBR 6023:2002 da Associação Brasileira de Normas Técnicas (ABNT):

MALUF, Sérgio Roberto. A pesagem dos veículos ônibus do transporte coletivo rodoviário interestadual de passageiros nas estradas federais. A\&C Revista de Direito Administrativo \& Constitucional, Belo Horizonte, ano 8, n. 33, p. 115-134, jul./set. 2008. 